Improved performance of partly pit exhaust systems in pig housing

Bjerg, Bjarne Schmidt; Riis, Anders Leegaard; Zhang, Guoqiang

Published in:

ASABE / CSBE/ASABE Joint Meeting Presensation

Publication date:

2014

Document version

Early version, also known as pre-print

Citation for published version (APA):

Bjerg, B. S., Riis, A. L., \& Zhang, G. (2014). Improved performance of partly pit exhaust systems in pig housing.

In ASABE / CSBE/ASABE Joint Meeting Presensation [141899147] American Society of Agricultural and

Biological Engineers. 


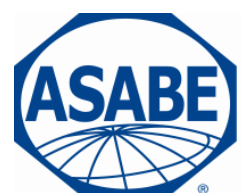

2950 Niles Road, St. Joseph, MI 49085-9659, USA 269.429.0300 fax 269.429.3852 hq@asabe.org www.asabe.org

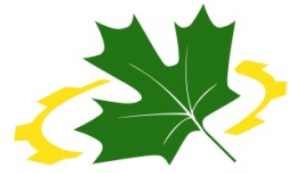

An ASABE - CSBE/ASABE Joint

Meeting Presentation

CSBE | SCGAB

Paper Number: 141899147

\title{
Improved performance of partly pit exhaust systems in pig housing
}

\author{
Bjarne Bjerg, University of Copenhagen, Denmark \\ Anders Leegaard Riis, Pig Research Centre, Denmark \\ Guoqiang Zhang, Aarhus University, Denmark
}

\author{
Written for presentation at the \\ 2014 ASABE and CSBE/SCGAB Annual International Meeting \\ Sponsored by ASABE \\ Montreal, Quebec Canada
}

July $13-16,2014$

\begin{abstract}
.
Commercial chemical or biological air cleaning systems are capable to remove more than $90 \%$ of the ammonia in exhaust air from mechanical ventilated pig housing, but it is costly to install cleaning systems large enough to treat the large amount of air needed in warm periods. Introduction of partly pit ventilations systems where the first $10 \%$ of ventilation capacity is expelled through local exhaust located in the pit beneath the slatted floor can reduce pollutant concentration in the room, and simultaneously remove a large part of the pollutants in the small amount of expelled air from the pit. In addition this creates the preconditions for installing cost effective cleaning system that treats only the air expelled from the pit. CFD studies has shown that even though $10 \%$ of ventilation capacity is expelled from the pit there still are significant amount of air moving up through the slats and that observation indicates that changes in pen or pit design potentially may lead to improved performance of partly pit ventilation systems. One option is to reduce the openings of the slatted floor, but this may have a negative consequence of accumulated urine and manure on the floor and can therefor potentially increase the total ammonia emission. Another option is to place plates (or curtains) in the pit to reduce the air movement beneath the slats, and the effects of this method are investigated in this study. The study includes CFD and full scale measurement, and shows that plates or curtains in the pit significantly can improve the performance of a partly pit ventilation system.
\end{abstract}

\section{Keywords.}

Ammonia emission, partly pit ventilation, CFD, air cleaning. 


\section{Introduction}

Commercial chemical or biological air cleaning systems are capable to remove more than $90 \%$ of the ammonia in exhaust air from mechanical ventilated pig housing, but it is costly to install cleaning systems large enough to treat the large amount of air needed in warm periods. Danish farmers who want to expand their livestock production are usually obligated to take measures that can reduce the expected ammonia emission from the planned housing. The reduction required is, however, usually less than $60 \%$ and can therefore be met by cleaning only a part of the exhaust air. In temperate climate zones the air change required in pig housing is less than the maximum ventilation capacity in most of the time during the year, and therefore it can be effective to treat a defined amount of the exhaust air only.

Both measurement and modeling studies shows that treatment of $20 \%$ of the ventilation capacity is sufficient to reduce the ammonia emission by approximately $70 \%$. In slatted floor pig housing the highest ammonia concentration is found in the pit in the resting area beneath the slatted floor, and therefore, the effectiveness of cleaning a defined amount of the exhaust air can be improved by using partly pit air exhaust together with pit exhaust air cleaning. As average for a whole year on farm measurement shows that at least $65 \%$ of the ammonia emission, $47 \%$ of the odour emission and $52 \%$ of the hydrogen sulphide emissions can be collected by a partly pit air exhaust in a flow rate of $10 \%$ percent of the ventilation capacity (Riis et al., 2014b). Bjerg and Zhang (2013) compared different ventilations configurations in CFD analyses of the ammonia emissions from a finisher pig unit with two third fully slatted floor (opening ratio $=0.16$ ) and one third drain floor (opening ratio 0.08 ), and found the similar results as in the on-farm measurements. Never the less, further examination of the simulations results revealed that a significant amount of air moves upward through the floor slats although a partly pit air exhaust was used. It indicates that changes in pen or pit design potentially may lead to improved performance of partly pit ventilation systems. One option is to reduce the openings of the slatted or drained floor, but this may have a negative consequence of accumulated urine and manure on the floor and, that can therefore potential increase the total ammonia emission. Another option is to place plates (or curtains) in the pit to reduce the air movement beneath the slats, and the effects of this method are investigated by CFD and full scale measurement in this study.

\section{Methods}

\section{CFD modeling}

The commercial CFD code Ansys Fluent 12 (Ansys Fluent, 2009), and the Realizable k- $\varepsilon$ turbulence model (Shih et al. 1995) was used to calculate the thermal air flow and ammonia distribution in one half pen section of a fully drained pen for finisher pig, see Figure 1.

The developed geometrical model consists of 464620 hexahedral and 5481 tetrahedral cells, and was designed to conduct the simulations with partly pit exhaust, with or without plates to restrict the airflow in pit headspace. It was assumed the pit headspace was $0.4 \mathrm{~m}$ high and the plates were located one third from each end of the pen to divide the pit in three equal size parts. To allow a limited air movement between the compartments a $0.1 \mathrm{~m}$ gap between the plates and the slats is held open.

An overview over the used boundary conditions is given in Figure 2. For prediction of ammonia release were assumed a constant ammonia concentration on the floor surfaces of $20 \mathrm{ppm}$ and a $94 \mathrm{ppm}$ constant ammonia concentration on the surface of the slurry in the pit. More details on the development of this and other assumptions used in the simulations are available in Bjerg and Zhang (2013).

The authors are solely responsible for the content of this meeting presentation. The presentation does not necessarily reflect the official position of the American Society of Agricultural and Biological Engineers (ASABE), and its printing and distribution does not constitute an endorsement of views which may be expressed. Meeting presentations are not subject to the formal peer review process by ASABE editorial committees; therefore, they are not to be presented as refereed publications. Citation of this work should state that it is from an ASABE meeting paper. EXAMPLE: Author's Last Name, Initials. 2014. Title of Presentation. ASABE Paper No. ---. St. Joseph, Mich.: ASABE. For information about securing permission to reprint or reproduce a meeting presentation, please contact ASABE at rutter@asabe.org or 269-932-7004 (2950 Niles Road, St. Joseph, Ml 49085-9659 USA). 

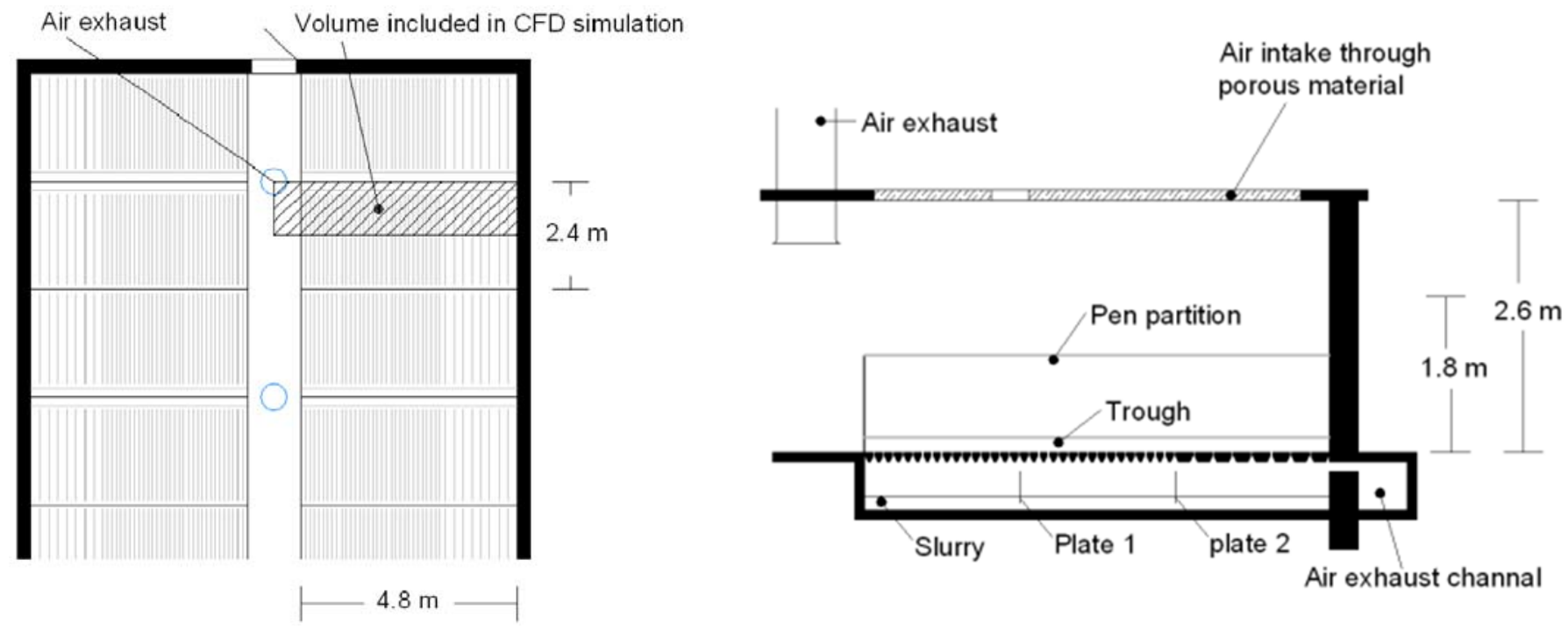

Figure 1. Plan and cross section of assumed finisher pig unit with plates for delimitation of air movement in slurry pit.

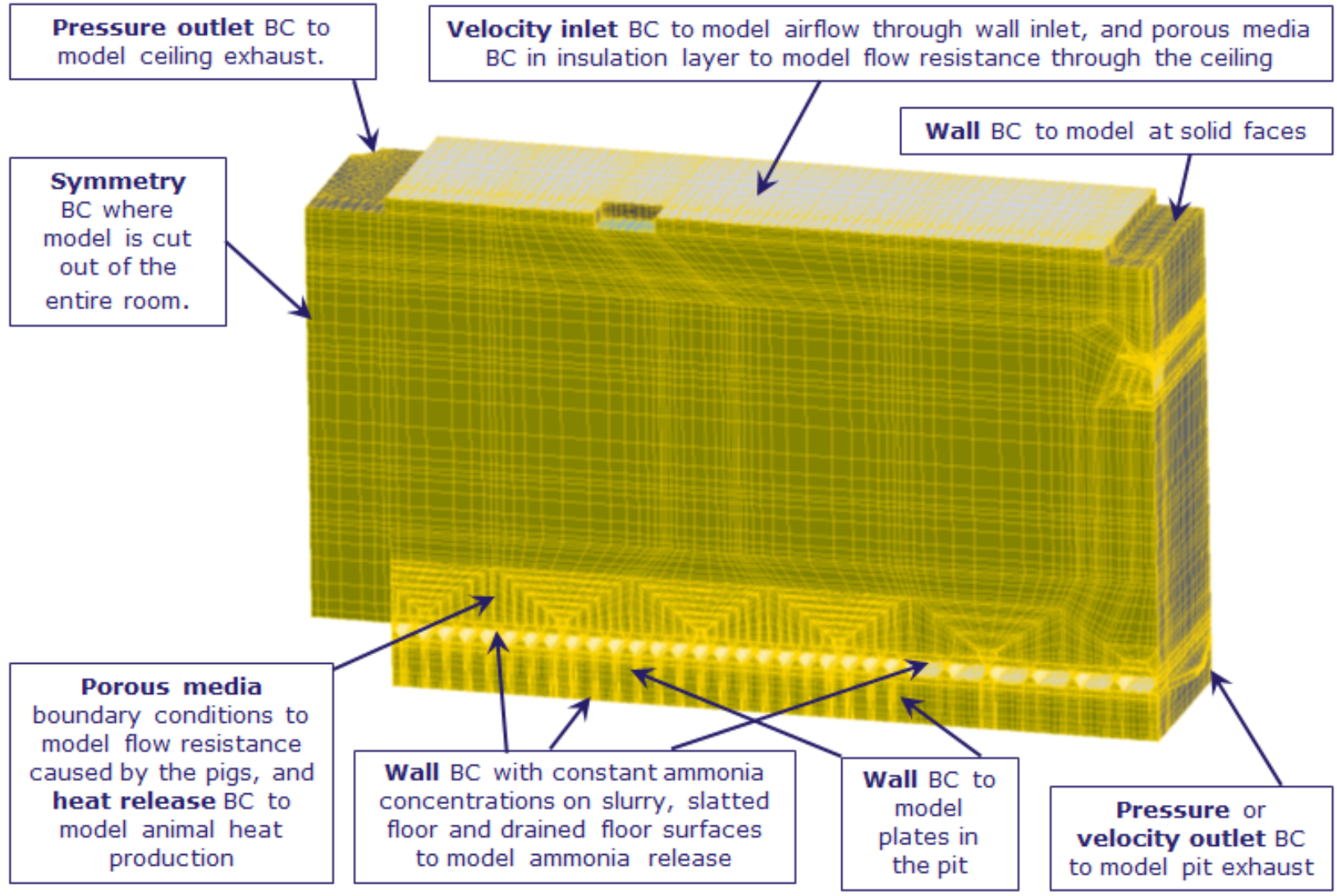

Figure 2. Geometry, grid on surfaces and boundary conditions $(B C)$ used in CFD simulations. 


\section{Full scale measurements}

The field measurements were conducted in two sections of an existing commercial finisher building. The sections were equipped with 22 pens designed for 16 pigs per pen, and a total of 352 pigs per section, see Figure 3.

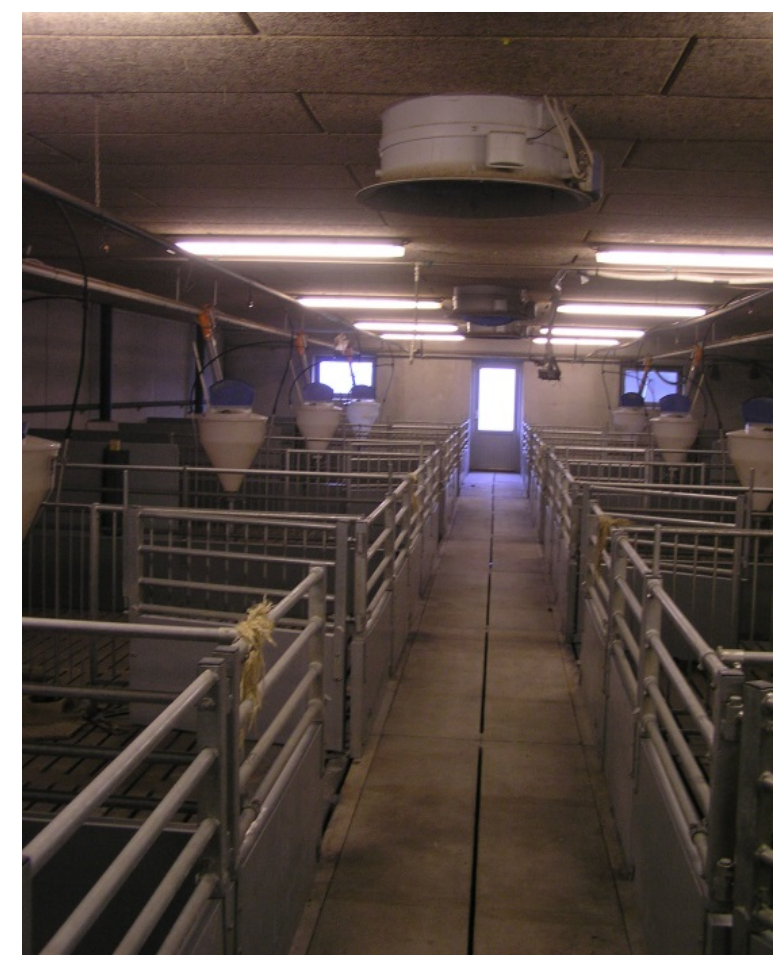

Figure 3. Finisher pig section used for full scale measurements.

During the measurements the barn was used for gilts and, therefore the number of animal per pen was reduced to 12. The sections measured $26.3 \mathrm{~m}$ in length and $10.7 \mathrm{~m}$ in width and the ceiling height was $2.6 \mathrm{~m}$. The pens measured $4.8 \mathrm{~m}$ in length and $2.4 \mathrm{~m}$ in width. The pens had a $2.5 \mathrm{~m}$ drain floor in lying area against the wall and $2.3 \mathrm{~m}$ slatted floors dunging area by the aisle. The slurry pits were $0.70 \mathrm{~m}$ deep.

The barn had diffuse ceiling air inlet in two layers of $50 \mathrm{~mm}$ glass wool with a $25 \mathrm{~mm}$ wood wool plate beneath. The room exhaust capacity in each section consisted of one stepless and two on/off ceiling exhausts units. The pit exhausts consisted of vertical $160 \mathrm{~mm}$ suction tubes with openings below the drain floor at the wall end of the lying area in between each second pen (see Figure 4 to the left). The air from the twelve suction tubes was collected into a single exhaust unit in the attic; see Figure 4 to the right.

A former work (Riis et al., 2014b) using the same facility including an experimental unit where the first $10 \%$ of the required ventilations was expelled through the pit exhaust and a control unit without pit exhaust showed that pit exhaust system reduced the ammonia emission through the ceiling exhaust from 0.19 to $0,10 \mathrm{~g} \mathrm{NH} 3-\mathrm{N}$ $\mathrm{h}^{-1} \mathrm{pig}^{-1}$, corresponding to a $47 \%$ reduction. In this work a unit was equipped with a slurry curtain in the pit in each pen located beneath the transition between the drain and slatted floor. The curtains were adjustable in height so it became possible to adjust the height of the gap between curtain and the slatted floor. As a reference, another unit without pit curtain was chosen. Both units were operated with a partly pit air exhaust in $10 \%$ of the designed capacity of the units, which is equivalent to $10 \mathrm{~m}^{3} \mathrm{pig}^{-1} \mathrm{~h}^{-1}$ for growing-finishing pig housing in Denmark. 

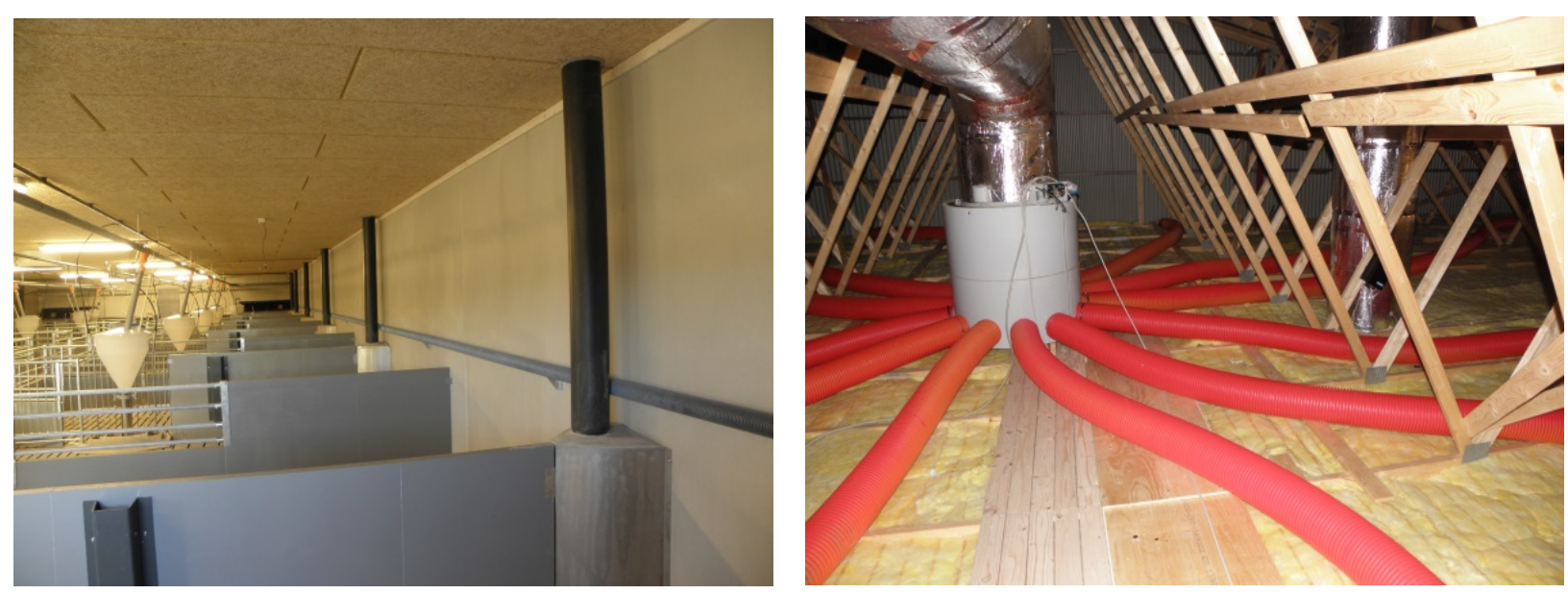

Figure 4. Pit exhaust suction tubes between each second pen (to the left) and combining of twelve pit exhaust suction tubes to a single exhaust in the attic (to the right).

The study where conducted during the following three periods

1. September $16^{\text {th }}$ to $23^{\text {th }} 2013$

2. September $24^{\text {th }}$ to October $26^{\text {th }} 2013$

3. March $23^{\text {th }}$ to April $7^{\text {th }} 2014$

The gap between the curtains and the slatted floor where adjusted to $15 \mathrm{~cm}$ during period 1 and to $7 \mathrm{~cm}$ during period 2 and 3.

The ammonia concentrations in the different exhausts and in the outdoor air were measured continuously with infrared spectrometry (INNOVA 1412 photo acoustic gas analysis and 1309 Multipoint Sampler, (www.lumasenseinc.com)). The ceiling exhaust air change was measured and controlled by a Dynamic Air system from SKOV (www.skov.com) and the pit exhaust was measured by a Fancom fan-wheel anemometer (www.fancom.com) in the combined pit exhaust in the ceiling.

\section{Results and Discussion}

\section{Numerical simulations}

Figure 5 shows simulated vertical velocity in the floor slots without plates, with plate 1 only and with both plates (see Fig. 1), at $10 \mathrm{~m}^{3} \mathrm{pig}^{-1} \mathrm{~h}^{-1}$ pit exhaust and $90 \mathrm{~m}^{3} \mathrm{pig}^{-1} \mathrm{~h}^{-1}$ ceiling exhaust. From Table 1 one it appears that plate 1 only reduce the amount of air moving up through the floor slots by $56 \%$. In addition plate 1 reduced the ammonia emission by $25 \%$, and using both plates this reduction was $41 \%$.

It also appears from table from Table 1 that the combination of $10 \mathrm{~m}^{3} \mathrm{pig}^{-1} \mathrm{~h}^{-1}$ pit exhaust and the two plates result in an equal reduction of ammonia emission through the ceiling exhaust as using $20 \mathrm{~m}^{3} \mathrm{pig}^{-1} \mathrm{~h}^{-1}$ pit exhaust without plates. 

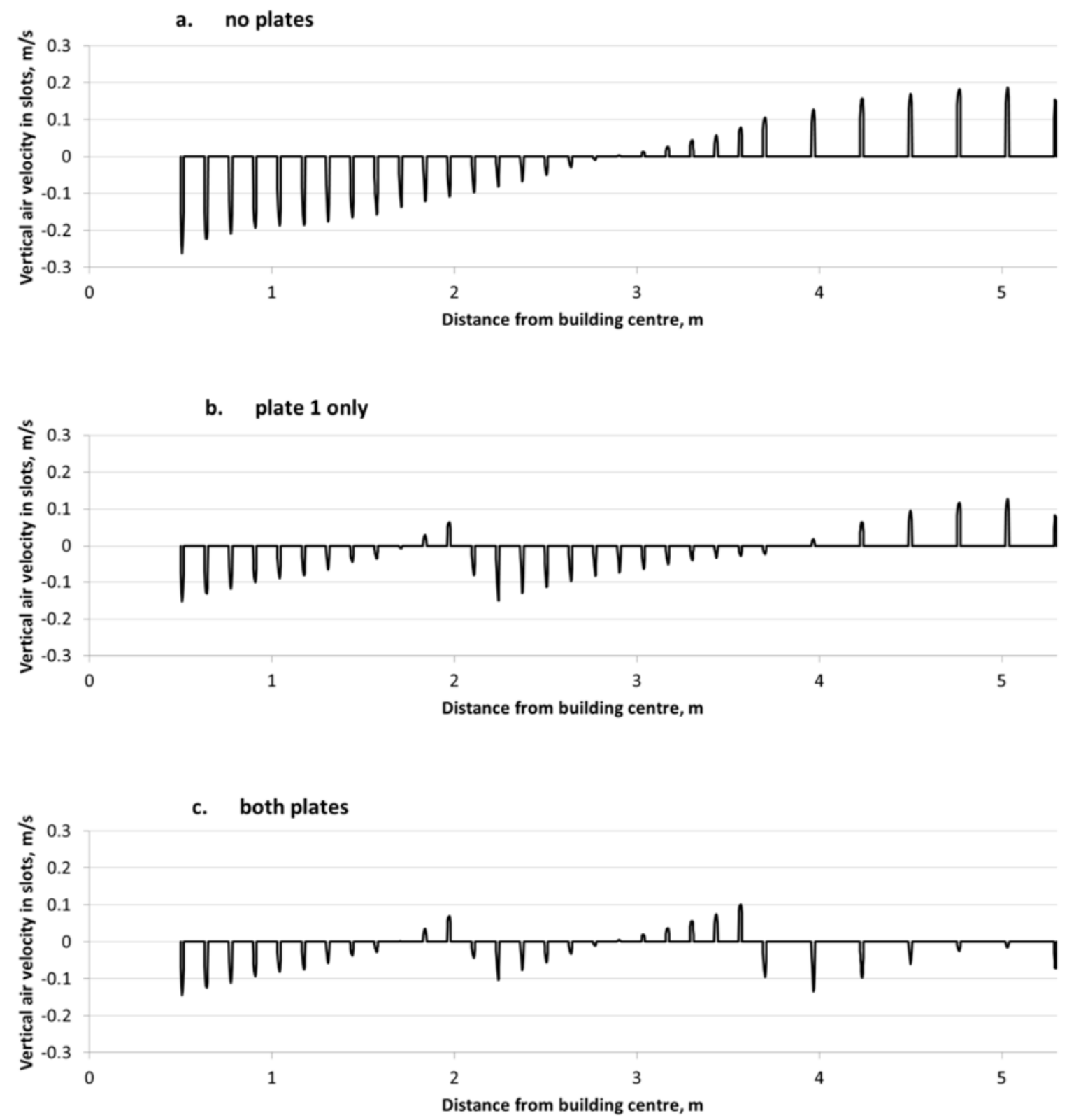

Figure 5. Simulated vertical air velocity in floor slots.

Table 1. Amount of air moving up through floor slots, and ammonia emission at total air change of $100 \mathrm{~m}^{3} \mathrm{pig}^{-1}$ $h^{-1}$. Figures in brackets is relative to the level with no plates and $10 \mathrm{~m}^{3} \mathrm{pig}^{-1} \mathrm{~h}^{-1}$ pit exhaust.

\begin{tabular}{lcccc}
\hline Setup & $\begin{array}{c}\text { Pit ventilation } \\
\mathrm{m}^{-3} \mathrm{pig}^{-1} \mathrm{~h}^{-1}\end{array}$ & $\begin{array}{c}\text { Air moving up through } \\
\text { floor slots, } \mathrm{m}^{-3} \mathrm{pig}^{-1} \mathrm{~h}^{-1}\end{array}$ & \multicolumn{2}{c}{ Ammonia emission, $g \mathrm{NH}_{3}-\mathrm{N} \mathrm{h}^{-1} \mathrm{pig}^{-1}$} \\
\cline { 4 - 5 } No plates & 10 & $12.2(100)$ & $0.128(100)$ & $0.300(100)$ \\
Plate 1 only & 10 & $5.4(44)$ & $0.095(75)$ & $0.281(94)$ \\
Both plates & 10 & $3.6(30)$ & $0.075(59)$ & $0.250(83)$ \\
No plates & 20 & $6.7(55)$ & $0.074(58)$ & $0.336(112)$ \\
No plates & 40 & $0(0)$ & $0.019(15)$ & $0.408(136)$ \\
\hline
\end{tabular}




\section{Full scale measurements}

As average of the results in the three measurement periods showed that the slurry curtains reduced the emission via ceiling exhaust by $44 \%$ and the total emission by $25 \%$, see table 2, comparing with the data without pit curtains reported by Riis et al. (2014b).

Table. 2. Measured ammonia emission $\left(\mathrm{g} \mathrm{NH}_{3}-\mathrm{N} \mathrm{h}^{-1} \mathrm{pig}^{-1}\right)$ at $10 \%$ pit exhaust with and without pit curtains

\begin{tabular}{ccccccc}
\hline & \multicolumn{3}{c}{ Ceiling exhausts emission } & \multicolumn{3}{c}{ Total emission } \\
Study period & without curtains & with curtains & $($ diff.) & without curtains & with curtains & (diff.) \\
\hline 1 & 0.12 & 0.074 & $(-39 \%)$ & 0.174 & 0.131 & $(-25 \%)$ \\
2 & 0.19 & 0.12 & $(-37 \%)$ & 0.275 & 0.180 & $(-35 \%)$ \\
3 & 0.11 & 0.048 & $(-56 \%)$ & 0.185 & 0.158 & $(-15 \%)$ \\
\hline
\end{tabular}

\section{Discussion and conclussions}

Both simulation and full scale measurement resulted in a significant reduction of ammonia emission through the ceiling exhausts by installing plates or curtains in the pit of a partly pit ventilated finisher unit. The effect was apparently larger in the full scale measurement than in the simulation, but it is not clear whether this difference is caused by limitations in the used simulations methods or by the differences in the configuration of the used setup in measurements and simulations. Potential important differences between the setups used in measure and simulation were:

- Different locations of curtains (or plates).

- Different gap heights between the curtains (or the plates) and the slatted floor.

- Different heights of the pit headspace.

- Different total ventilation rates $\left(100 \mathrm{~m}^{3} \mathrm{pig}^{-1} \mathrm{~h}^{-1}\right.$ in simulation vs. $24-83 \mathrm{~m}^{3} \mathrm{pig}^{-1} \mathrm{~h}^{-1}$ in full scale measurement).

- Different distances between pit exhaust opening positions (1.2 $\mathrm{m}$ in simulations vs. $4.8 \mathrm{~m}$ in full scale measurements).

Measurements were conducted at two different gap height between the curtains and the slatted floor (15 or 7 $\mathrm{cm}$ ), but the results was insufficient to determine which of them that performed best.

Based on simulation results two plates seem to be significant more effective than only one.

In general the results showed a significant improvement of the efficiency of partly pit ventilation systems by introducing of curtains (or plates) in the slurry pit. Potentially the method might be included as an ammonia emission reduction technology in national legislations systems, but firstly it will require a clarification of the conditions that must be met in order to take the technique in to consideration at approval of livestock production units, and, secondly, it will require a determination of the size of the environmental effect the technique should be given when these conditions are met.

\section{References}

Ansys Fluent (2009). Ansys Fluent 12.0 User's Guide.

Bjerg, B., Zhang, G. (2013). CFD Analyses of the Influence of Ventilation System on the Effectiveness of a Partial Pit Exhaust. Acta hort 1008.

Riis, A. L., Jørgensen, M.,Hansen, P. (2014a). 10 \% punktudsugning via sugepunkt midt under lejeareal i slagtesvinestald med drænet gulv i lejearealet (10\% local exhaust ventilation via the suction point below resting area in a finisher unit with drained floor in the lying area.) Report 998 from the Danish Pig Research Centre

Riis, A.L., Jørgensen, M., Hansen, P. (2014b) 10 \% punktudsugning via sugepunkt under hver 2.stiadskillelse i slagtesvinestald med drænet gulv i lejearealet (10\% local exhaust ventilation via the suction point below each second pen partition in a finisher unit with drained floor in the lying area.) Report 999 from the Danish Pig Research Centre.

Shih, T.-H.; Liou, W. W.; Shabbir, A., Zhu J. (1995). A new k- $\varepsilon$ eddy viscosity model for high Reynolds number turbulent flows. Computer Fluids. Vol 24, No 3, pp 227-238. 